\title{
Hepatitis associated with amoxycillin-clavulanic acid combination report of 15 cases
}

\author{
D Larrey, T Vial, A Micaleff, G Babany, M Morichau-Beauchant, H Michel, J P Benhamou
}

\begin{abstract}
Fifteen cases of hepatitis related to a combination of amoxycillin and clavulanic acid are reported. Most patients were aged 60 years or more and there were more men than women (sex ratio 4:1). The amoxycillin-clavulanic acid had been given at doses ranging from 0.5 to $6 \mathrm{~g} /$ day (mean 2 g/day) for seven to 60 days (mean 18 days). In 11 cases, the first symptoms appeared one to four weeks after stopping treatment. Jaundice was observed in all patients and was frequently associated with pruritus. Serum aminotransferase activities were increased in all patients and were generally two to $\mathbf{1 0}$ times the upper limit of normal. Serum alkaline phosphatase activity was considerably increased, from two to seven times the upper limit of normal. Histological examination of the liver, performed in seven patients, showed centri- or panlobular cholestasis in all cases, associated with granulomatous hepatitis in one. The prognosis of amoxycillin-clavulanic acid induced hepatitis seemed to be good. None of the patients exhibited biological or clinical features of hepatic failure and the course of the disease was characterised by the resolution of jaundice within one to eight weeks and a complete recovery within four to $\mathbf{1 6}$ weeks. Taking into account the number of treated subjects and reported cases, we estimated the risk of developing hepatitis with this drug combination to be very low, probably below $1 / 100000$. Our data suggest that the risk of hepatotoxicity may be increased in elderly men given lengthy treatment. The association of hepatitis and signs of hypersensitivity may suggest an immunoallergic mechanism of hepatotoxicity in some patients.
\end{abstract}

Amoxycillin, a semisynthetic penicillin, has been combined with clavulanic acid, an inhibitor of bacterial $\beta$-lactamases, to decrease antimicrobial resistance. This combination, first marketed in France in 1984, is one of the most prescribed antibiotics worldwide. ${ }^{2}$ In France, in each oral brand, the ratio of amoxycillin to clavulanic acid (w/w) is $4 / 1$. The administration of amoxycillinclavulanic acid is associated with a moderate and asymptomatic increase in serum aminotransferase activity in $23 \%$ of subjects. ${ }^{3}$ Since 1989,32 cases of acute hepatitis have been described. ${ }^{+12}$ In addition, the Australian Adverse Drug Reactions Advisory Committee recently noted (without individual details) the receipt of 30 reports of hepatic dysfunction after amoxycillinclavulanic acid administration. ${ }^{13}$ In most cases, hepatitis related to amoxycillin-clavulanic acid exhibited cholestatic patterns; hepatocellular or mixed cholestatic and hepatocellular patterns have been described less frequently. ${ }^{+13}$

These data prompted a study which aimed to assess amoxycillin-clavulanic acid hepatotoxicity in France, on the basis of cases observed in several hospital liver units or spontaneously reported to the regional centres of the French System of Drug Surveillance (Pharmacovigilance centres) $)^{1+}$ and to the manufacturer, Beecham Laboratories.

In this report, we describe 15 cases compiled during this collaborative study, including one case recently published " and one case accepted for publication as a letter. ${ }^{15}$ Our data confirm that amoxycillin-clavulanic acid generally causes acute cholestatic hepatitis and show that this drug combination may also occasionally induce granulomatous hepatitis. In addition, this study shows that the risk of hepatotoxicity is low and is mainly associated with elderly men receiving lengthy treatment.

\section{Methods}

Forty patients with hepatitis possibly related to amoxycillin-clavulanic acid administration were seen in several liver units or were reported to regional centres of the national drug surveillance network and Beecham Laboratories, France between January 1987 and June 1990. In all cases, clinical, biological, and pathological data were carefully reviewed.

In 25 cases the available data were considered to be insufficient to exclude other causes of hepatitis. In the remaining 15 patients (see Tables I and II), hepatitis was ascribed to amoxycillin-clavulanic acid administration on the following grounds. These patients had no history of liver or biliary tract disease or of drug addiction, transfusion of blood products, or surgery within the six months preceding the onset of hepatitis. Only one patient (case 9) was an abuser of alcohol. In all patients, IgM antibodies to hepatitis A virus and hepatitis B surface antigen were absent in serum. Serological tests for hepatitis $C$ virus infection were negative in the six patients tested (patients $1,2,5,7,8,11$ ). Serological tests for recent infection with cytomegalovirus in nine cases (patients $1-8,11$ ), herpes simplex viruses in three patients (patients $1,2,8)$, and Epstein-Barr virus in six patients (patients $1,2,5,7,8,11$ ) were also negative in all patients tested. Ultrasonography of the liver and biliary tract was normal in all cases. Computed tomography of the liver and biliary tract, undertaken in five patients (patients $6,9,10,11,15$ ) was normal, as was endoscopic retrograde cholangiography performed in eight patients (patients $1,3,4,5,6,7,11,13$ ). In all patients, there was a clear chronological relation between

Service des Maladies de
l'Appareil Digestif,
Hôpital Saint-Eloi,
Montpellier, France
D Larrey
H Michel
Centre de
Pharmacovigilance,
Hôpital Edouard-Herriot,
Lyon, France
T Vial
Service d'Hépatologie,
Hôpital Beaujon, Clichy,
France
J P Benhamou
Service d'Hépato-
Gastroentérologie, CHR
Poitiers, France
M Morichau-Beauchant
G Babany
Les Laboratoires
Beecham, France
A Micaleff
Correspondence to:
Dr D Larrey, Service des
Maladies de l'Appareil
Digestif, Hopital Saint-Eloi,
Avenue Bertin Sans, 34059
Montpellier, France.
Accepted for publication
23 July 1991

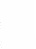

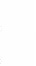


TABLE I Age, sex, and drug administration in 15 patients with amoxycillin-clavulanic acid induced hepatitis

\begin{tabular}{|c|c|c|c|c|c|c|c|c|c|}
\hline \multirow[b]{2}{*}{$\begin{array}{l}\text { Patient } \\
\text { no }\end{array}$} & \multirow[b]{2}{*}{$\begin{array}{l}\text { Sex/age } \\
\text { (years) }\end{array}$} & \multicolumn{6}{|c|}{ Amoxycillin-clavulanic acid administration } & \multirow[b]{2}{*}{ Other administered drugs } & \multirow[b]{2}{*}{$\begin{array}{l}\text { Previous } \\
\text { administration } \\
\text { of amoxicillin }\end{array}$} \\
\hline & & $\begin{array}{l}\text { Dosage } \\
(\text { g/day })\end{array}$ & $\begin{array}{l}\text { Duration of } \\
\text { treatment } \\
\text { (days) }\end{array}$ & $\begin{array}{l}\text { Total } \\
\text { dose }(g)\end{array}$ & $\begin{array}{l}\text { Interval } \\
\text { from onset of } \\
\text { treatment to } \\
\text { onset of } \\
\text { hepatitis } \\
\text { (days) }\end{array}$ & $\begin{array}{l}\text { Interval } \\
\text { from stopping } \\
\text { treatment to } \\
\text { onset of } \\
\text { hepatitis } \\
\text { (days) }\end{array}$ & Indication & & \\
\hline 1 & $M / 48$ & $0.5-0.75$ & 21 & 13 & 29 & 8 & Bronchitis asthma & Theophylline, terbutaline, salbutamol & Yes \\
\hline 2 & $\mathrm{~F} / 52$ & $3 \cdot 0$ & 15 & 45 & 45 & 30 & $\begin{array}{l}\text { Upper respiratory } \\
\text { tract infection }\end{array}$ & $\begin{array}{l}\text { Ketoprofen, metronidazole, } \\
\text { netromycin, ranitidine, } \\
\text { bethamethasone }\end{array}$ & No \\
\hline 3 & $\mathrm{M} / 50$ & $1 \cdot 0$ & 7 & 7 & 7 & 0 & Sinusitis & Hydroxyzine, carbocystein, framycetin & No \\
\hline 4 & $\mathrm{M} / 73$ & $6 \cdot 0$ & 24 & 144 & 42 & 17 & Endocarditis & $\begin{array}{l}\text { Netromycin, clonidine, furosemide, } \\
\text { digoxine, lorazepam, clobazepam }\end{array}$ & No \\
\hline 5 & $\mathrm{M} / 57$ & $1 \cdot 5$ & 17 & $25 \cdot 5$ & 35 & 18 & Bronchitis asthma & $\begin{array}{l}\text { Prednisolone, salbutamol, } \\
\text { theophylline, beclomethasone, } \\
\text { sodium nedocromil, ipratropium } \\
\text { bromide }\end{array}$ & No \\
\hline 6 & $\mathrm{M} / 82$ & $2 \cdot 0-3 \cdot 0$ & 15 & 34 & 38 & 23 & Bronchitis & Furosemide & No \\
\hline 7 & $\mathrm{M} / 79$ & $1 \cdot 5$ & 15 & $22 \cdot 5$ & 35 & 20 & $\begin{array}{l}\text { Urinary tract } \\
\text { infection }\end{array}$ & $\begin{array}{l}\text { Heptaminol, raubasine- } \\
\text { dihydroergocristine }\end{array}$ & No \\
\hline 8 & $\mathrm{M} / 50$ & $1 \cdot 5$ & 12 & 18 & 13 & 1 & $\begin{array}{l}\text { Upper respiratory } \\
\text { tract infection }\end{array}$ & Roxithromycin & Yes \\
\hline 9 & $\mathrm{M} / 75$ & $1 \cdot 0-2 \cdot 0$ & 10 & 30 & 38 & 18 & Ocular infection & Diclofenac, sucralfate, levodopa & No \\
\hline 10 & $\mathrm{M} / 82$ & $1 \cdot 5-2 \cdot 0$ & 60 & 100 & 89 & 29 & Bronchitis & Prednisolone, roxithromycin & Yes \\
\hline 11 & $M / 62$ & $3 \cdot 0$ & 14 & 42 & 21 & 8 & Unknown & Ketoprofen, paracetamol, enoxaparine & No \\
\hline 12 & $M / 67$ & $2 \cdot 0$ & 10 & 20 & 22 & 12 & Pneumonia & $\begin{array}{l}\text { Diltiazem, pindolol, prednisolone, } \\
\text { theophylline, acetylcystein }\end{array}$ & No \\
\hline 13 & $M / 81$ & $2 \cdot 0-3 \cdot 0$ & 33 & 71 & 33 & 0 & Pneumonia & $\begin{array}{l}\text { Digoxine, trinitrine, indapamine, } \\
\text { nicardipine, ticlopidine, lisinopril }\end{array}$ & No \\
\hline 14 & $\mathrm{~F} / 63$ & $1 \cdot 5$ & 7 & $10 \cdot 5$ & 29 & 3 & Otitis & Niflumic acid & Yes \\
\hline 15 & M/39 & Unknown & 10 & Unknown & 28 & 20 & $\begin{array}{l}\text { Upper respiratory } \\
\text { tract infection }\end{array}$ & $\begin{array}{l}\text { Prednisolone, amphotericine B, } \\
\text { nitrazepam, serrapeptase }\end{array}$ & Yes \\
\hline
\end{tabular}

amoxycillin-clavulanic acid administration and the onset of hepatitis, as well as between withdrawal of the treatment and the resolution of liver dysfunction. The direct involvement of other drugs in the hepatitis could be eliminated on the basis of clinical or chronological data.

\section{Results}

Age, sex, and drug administration as well as clinical, biological, and histological manifestations observed in our 15 cases are summarised in Tables I and II.

The ages of the patients with hepatitis ranged from 39 to 82 years (mean 64 years), and there were more men than women (12 $v 3$ cases; sex ratio $4: 1)$. The amoxycillin-clavulanic acid had been given at doses ranging from 0.5 to $6 \mathrm{~g}$ /day $(0 \cdot 5-3 \mathrm{~g}$ orally; $2-6 \mathrm{~g}$ iv) (mean $2 \mathrm{~g} /$ day) with a duration of administration ranging from seven to 60 days (mean 18 days). The cumulative dose varied widely, between 7 and $144 \mathrm{~g}$ (mean $42 \mathrm{~g}$ ). Hepatitis occurred seven to 89 days (mean 33 days) after starting the treatment. In 11 patients, amoxycillin-clavulanic acid had already been stopped for one to four weeks when the first symptoms of hepatitis were observed. In most cases, amoxycillin-clavulanic acid was given for mild or moderately severe infection of the upper respiratory tract or for moderate bronchitis. Only three patients were receiving treatment for severe infections: endocarditis, bronchitis, and pneumonia. Five patients had previously received amoxycillin alone, without adverse effect.

All patients had jaundice, which was intense (serum bilirubin $>100 \mu \mathrm{mol} / \mathrm{l}$ ) in 12 . It was associated with pruritus in 12, asthenia in seven, and with vomiting, nausea, hepatomegaly, and skin rash in one case each.

Serum alanine and aspartate aminotransferase activities were increased in all patients - they ranged from two to 10 times the upper limit of normal in 11 cases, and were 10 to 20 times the upper limit of normal in four. Serum alkaline phosphatase activity was appreciably increased, with values ranging from two to seven times the upper limit or normal. Similarly, serum $\gamma$ glutamyl transpeptidase activity exceeded 10 times the upper limit of normal in eight of the 12 patients tested. The 15 patients did not exhibit any clinical or biological features of hepatic failure (data not shown in the two Tables). Hepatitis was associated with blood hypereosinophilia (eosinophils $>400 / \mathrm{mm}^{3}$ ) in five patients. Results of tests for serum antitissue antibodies were available in 10 patients. Positive results with low or moderate titres $(<1 / 100)$ were found for antinuclear antibodies in three, for antismooth muscle antibodies in one, and for antimitochondrial antibodies in one case.

A liver biopsy was performed in seven patients and histological examination showed centrilobular or panlobular cholestasis in all. It was associated with granulomatous hepatitis in one patient. The course of the hepatitis was generally characterised by prompt improvement of liver dysfunction. The long term outcome of hepatitis could be assessed in nine patients. In these cases, jaundice resolved within one to eight weeks and liver tests returned to normal within four to 16 weeks.

Amoxycillin or mezlocillin, another $\beta$-lactam closely related to amoxycillin, was given to three patients after hepatitis. In one patient (case 1), amoxycillin was administered for three weeks after complete recovery without relapse of hepatitis. In the two other patients (patients 4 and 7), amoxycillin or mezlocillin was given while jaundice was still present and was associated with inconclusive fluctuation in liver test abnormalities. In collaboration with Beecham Laboratories, we tried to estimate the prevalence of amoxycillin-clavulanic acid hepatotoxicity 
TABLE II Clinical, biological, and histological manifestations in 15 patients with amoxycillin-clavulanic acid induced hepatitis

\begin{tabular}{|c|c|c|c|c|c|c|c|c|c|c|c|c|}
\hline \multirow{3}{*}{$\begin{array}{l}\text { Patient } \\
\text { no }\end{array}$} & \multirow{3}{*}{$\begin{array}{l}\text { Clinical } \\
\text { manifestations }\end{array}$} & \multirow{3}{*}{$\begin{array}{l}\text { Serum } \\
\text { bilirubin } \\
(\mu \mathrm{mol} / \mathrm{l})\end{array}$} & \multirow[b]{2}{*}{$A L T$} & \multirow[b]{2}{*}{$A S T$} & \multirow{3}{*}{ Alk Pho } & \multirow{3}{*}{$G G T$} & \multirow[b]{3}{*}{ Hypereosinophilia ${ }^{\star}$} & \multirow{3}{*}{\multicolumn{2}{|c|}{$\begin{array}{l}\text { Serum } \\
\text { antitissue } \\
\text { antibodies }\end{array}$}} & \multirow{3}{*}{$\begin{array}{l}\text { Histological } \\
\text { lesions }\end{array}$} & \multicolumn{2}{|c|}{ Course of the disease } \\
\hline & & & & & & & & & & & \multirow{2}{*}{$\begin{array}{l}\text { Duration } \\
\text { of jaundice } \\
\text { (weeks) }\end{array}$} & \multirow{2}{*}{$\begin{array}{l}\text { Duration of } \\
\text { liver test } \\
\text { abnormalities } \\
\text { (weeks) }\end{array}$} \\
\hline & & & \multicolumn{2}{|c|}{ ( $\times$ upper limit of normal $)$} & & & & & & & & \\
\hline 1 & $\begin{array}{l}\text { Jaundice, pruritus, } \\
\text { vomiting }\end{array}$ & 230 & 10 & 6 & 2 & 15 & + & $\begin{array}{l}\text { Anti-SM: } 1 \\
\text { Anti-Nu } \\
\text { Anti-Mit } \\
\text { Anti-LKM }\end{array}$ & $\begin{array}{l}150 \mathrm{e} \\
- \\
- \\
-\end{array}$ & $\begin{array}{l}\text { Centrilobular } \\
\text { cholestasis }\end{array}$ & 8 & 12 \\
\hline 2 & $\begin{array}{l}\text { Jaundice, pruritus, } \\
\text { skin rash, } \\
\text { asthenia }\end{array}$ & 152 & 4 & 1 & 3 & 9 & - & $\begin{array}{l}\text { Anti-Nu: } 1 \\
\text { Anti-SM } \\
\text { Anti-Mit } \\
\text { Anti-LKM }\end{array}$ & $\begin{array}{l}/ 100 \mathrm{e} \\
- \\
- \\
-\end{array}$ & $\begin{array}{l}\text { Centrilobular } \\
\text { cholestasis }\end{array}$ & Unknown & Unknown \\
\hline 3 & Jaundice, pruritus & 243 & 3 & 2 & 2,5 & 1,5 & - & $\begin{array}{l}\text { Anti-Nu } \\
\text { Anti-SM } \\
\text { Anti-Mit }\end{array}$ & $\begin{array}{l}- \\
- \\
-\end{array}$ & Cholestasis & 8 & Unknown \\
\hline 4 & $\begin{array}{l}\text { Jaundice, pruritus, } \\
\text { asthenia }\end{array}$ & 308 & 2 & 2 & 2 & 6 & + & $\begin{array}{l}\text { Anti-Nu: } 1 \\
\text { Anti-SM: } 1 \\
\text { Anti-Mit: }\end{array}$ & $\begin{array}{l}/ 160 \mathrm{e} \\
/ 40 \mathrm{e} \\
1 / 40 \mathrm{e}\end{array}$ & Cholestasis & 8 & $\begin{array}{l}>12 \\
<52\end{array}$ \\
\hline 5 & $\begin{array}{l}\text { Jaundice, pruritus, } \\
\text { asthenia }\end{array}$ & 280 & 18 & 10 & 6,5 & 29 & - & $\begin{array}{l}\text { Anti-Nu } \\
\text { Anti-SM } \\
\text { Anti-Mit } \\
\text { Anti-LKM }\end{array}$ & $\begin{array}{l}- \\
- \\
-\end{array}$ & $\begin{array}{l}\text { Panlobular } \\
\text { cholestasis }\end{array}$ & 2 & 8 \\
\hline 6 & $\begin{array}{l}\text { Jaundice, pruritus, } \\
\text { asthenia, } \\
\text { hepatomegaly }\end{array}$ & 317 & 2 & 2,5 & 2,0 & ND & - & Anti-Mit & - & Cholestasis & $>4$ & $<16$ \\
\hline 7 & Jaundice & 800 & 15 & 11 & 9 & 13 & + & $\begin{array}{l}\text { Anti-Nu } \\
\text { Anti-SM } \\
\text { Anti-Mit } \\
\text { Anti-LKM }\end{array}$ & $\begin{array}{l}- \\
- \\
-\end{array}$ & $\begin{array}{l}\text { Cholestasis } \\
\text { Granulomatous } \\
\text { hepatitis }\end{array}$ & 3 & 10 \\
\hline 8 & Jaundice, pruritus & 77 & 5,5 & 3 & 3,5 & 4,5 & - & ND & & ND & 4 & 8 \\
\hline 9 & Jaundice, pruritus & 202 & 9 & 8 & 7 & 19 & - & $\begin{array}{l}\text { Anti-Nu } \\
\text { Anti-SM } \\
\text { Anti-Mit }\end{array}$ & $\begin{array}{l}- \\
- \\
-\end{array}$ & ND & 3 & 5 \\
\hline 10 & Jaundice, pruritus & 279 & 3 & 1,5 & 7 & 11 & - & $\begin{array}{l}\text { Anti-Nu } \\
\text { Anti-SM } \\
\text { Anti-Mit }\end{array}$ & $\begin{array}{l}- \\
- \\
-\end{array}$ & ND & 8 & $>12$ \\
\hline 11 & Jaundice, pruritus & $\begin{array}{r}438 \\
71\end{array}$ & 2,5 & $\begin{array}{r}14 \\
8\end{array}$ & 2,5 & 13 & + & Anti-Mit & - & ND & 8 & $>8$ \\
\hline 13 & $\begin{array}{l}\text { Jaundice } \\
\text { Jaundice }\end{array}$ & 161 & $\begin{array}{l}10 \\
11\end{array}$ & $\begin{array}{l}8 \\
5\end{array}$ & $\begin{array}{l}2 \\
5\end{array}$ & $\begin{array}{l}26 \\
25\end{array}$ & - & $\begin{array}{l}\text { ND } \\
\text { ND }\end{array}$ & & ND & $\begin{array}{l}1 \\
3\end{array}$ & $\begin{array}{r}4 \\
>6\end{array}$ \\
\hline 14 & $\begin{array}{l}\text { Jaundice, pruritus, } \\
\text { asthenia, nausea }\end{array}$ & 57 & 4 & 2 & 5 & ND & + & ND & & ND & Unknown & $<16$ \\
\hline 15 & Jaundice, pruritus & 156 & 6 & 3 & 4 & ND & ND & ND & & ND & 3 & 2 \\
\hline
\end{tabular}

ALT $=$ serum alanine aminotransferase; AST $=$ serum aspartate aminotransferase; Alk Pho=serum alkaline phosphatase; GGT $=$ serum $\gamma$ glutamyl transpeptidase; ${ }^{*}$ Blood eosinophils $>400 / \mathrm{mm}^{3} ;$ Anti-SM $=$ anti-smooth muscle antibodies; anti-Nu=anti-nuclear antibodies; anti-Mit $=$ anti-mitochondrial antibodies; anti-LKM $=$ anti liver $/ \mathrm{kidney}$ microsome antibodies; +: present; -: absent; ND: not done

and to assess possible factors contributing to this adverse reaction.

Taking into account the number of cases of hepatitis ascribed to the amoxycillin-clavulanic combination, either reported ${ }^{+13}$ or collected in this study, and the estimated number of treated patients, the prevalence of symptomatic hepatitis was calculated to range from one to five/ 1000000 treated patients in several European countries including France, United Kingdom, Germany and Belgium. Obviously, these calculated values depend on the reporting rate for drug induced adverse reactions. Nevertheless, these data suggest that the risk of developing amoxycillinclavulanic acid hepatitis is very low, probably below 1/100 000 .

\section{Discussion}

Analysis of our 15 cases confirms previous reports showing that the amoxycillin-clavulanic acid combination may induce acute hepatitis, mainly exhibiting cholestatic features, and, less frequently, acute cytolytic or mixed pattern hepatitis. ${ }^{+13}$ One patient was affected by granulomatous hepatitis. It is noteworthy that there was frequently a delay of one to four weeks between stopping treatment and the onset of hepatitis in our study (Table I). A similar observation could be made by analysing patients reported by Reedy et al. ${ }^{+}$Such a feature is uncommon in drug induced liver injuries and makes diagnosis more difficult. ${ }^{16}$ The prognosis of amoxycillin-clavulanic acid induced hepatitis seems to be good. Indeed, in our patients, as well as in previously reported cases, ${ }^{+10}{ }^{12}$ there was no clinical or biological evidence of hepatic failure. Furthermore, after stopping the drug, the course of the disease was characterised by complete recovery within four months (Table II). ${ }^{+12}$

The mechanism of amoxycillin-clavulanic acid hepatitis is unknown. However, the frequent association of hepatitis with hypersensitivity manifestations (skin rash, hypereosinophilia, presence of serum antitissue autoantibodies) and the low prevalence of liver damage suggests an immunoallergic mechanism (Table II). ${ }^{+78}$

In addition, we identified several factors that may contribute to hepatotoxicity of this drug combination. Firstly, men were much more frequently affected than women (male/female sex ratio, $4: 1$ in our study). A similar predominance of men was also seen, albeit to a lesser extent (sex ratio 2:1), in other reported cases. $^{+1012}$ This difference was not related to significantly more frequent prescription of the drug in men: $58 \%$ in men $v 42 \%$ in women for subjects of all ages and $50 \%$ in men and women older than 65 years (data provided by Beecham Laboratories). Hypothetically, this may reflect some sexual influence in amoxycillin-clavulanic acid hepatotoxicity. Secondly, amoxycillinclavulanic acid hepatitis seems to be influenced by age - elderly subjects being more frequently affected. Nine of our 15 patients and 15 of the 31 other reported cases, ${ }^{+1012}$ were 60 years old or 
more. In contrast, hepatitis occurs exceptionally in children, only a single case having been reported in patients younger than 18 years. $^{8}$ Thirdly, hepatotoxicity may also be time dependent. Indeed, the mean durations of treatment in our 15 patients (18 days) and in the 18 patients reported by Reedy et al (14 days), ${ }^{4}$ were about twice as long as the usual length of treatment calculated for all patients who have received the drug ( 8.4 days) (data provided by Beecham Laboratories). In addition, the proportion of subjects who were treated for more than 15 days is $33 \%$ in our series and $24 \%$ in the other reported cases, ${ }^{+1012}$ whereas it represents only $1 \%$ for all treated patients (data provided by Beecham Laboratories). These findings strongly suggest that prolonged treatment may increase the risk of hepatotoxicity with this drug combination. Several hypotheses may be proposed for this latter feature. Protracted treatment may increase the rate of immunisation against the drug; alternatively, it may be consistent with a mechanism of hepatotoxicity partially related to formation or accumulation, or both, of putative toxic metabolites. These points deserve further investigation.

In amoxycillin-clavulanic acid hepatotoxicity, the relative contribution of each compound or the role of the drug combination is not fully elucidated. The direct involvement of amoxycillin alone is unlikely. As far as we know, there is only one reported case of hepatitis caused by this compound, although it has been widely used for more than 15 years. ${ }^{18}$ Five of our patients had previously received amoxycillin alone without ill effect (Table I). Rechallenge with amoxycillin alone performed in three patients $\left({ }^{8}\right.$ and our first case) was not followed by a recurrence of hepatitis, whereas rechallenge with both compounds in two of these three cases resulted in relapse of liver injury. ${ }^{8}$ This latter observation suggests an involvement of clavulanic acid in hepatotoxicity. This view is supported by a previous report that clavulanic acid in association with another $\beta$-lactam antibiotic, ticarcillin, may have been responsible for the worsening of preexisting liver disease. ${ }^{19}$ Whether clavulanic acid hepatotoxicity is promoted by amoxycillin is still unknown. The potential contribution of other drugs to amoxycillin-clavulanic acid hepatotoxicity is also unknown.

In conclusion, these data confirm that treatment with amoxycillin-clavulanic acid may lead to acute hepatitis, mainly exhibiting cholestatic features. Occasionally, granulomatous hepatitis may be observed. A time interval of one to four weeks between stopping the treatment and the first manifestations is frequently present and may hinder diagnosis. Complete recovery occurs within 16 weeks. Hepatotoxicity caused by this drug combination might be mediated by an immunoallergic mechanism in some patients and seems to have a very low frequency. The risk of hepatotoxicity may be increased in elderly men receiving lengthy treatment.

We thank the Regional Centres of the French System of Drug Surveillance for their collaboration in the study.

1 Reading C, Cole $M$. Clavulanic acid: a beta-lactamase inhibiting beta-lactam from streptomyces clavuligerus. Antimicrob Agents Chemother 1977; 11: 852-7.

2 Labia R, Peduzzi J. Kinetics of beta-lactamase inhibition by clavulanic acid. Biochem et Biophys Acta 1978; 526: 572-9.

3 Iravani A, Richard GA. Amoxycillin-clavulanic acid versus cefaclor in the treatment of urinary tract infections and their effects on the urogenital and rectal flora. Antimicrob Agents Chemother 1986; 29: 107-11.

4 Reddy RK, Brillant P, Schiff ER. Amoxicillin-clavulanate potassium-associated cholestasis. Gastroenterology 1989; 96 : potassium $1135-41$.

5 Verhamme M, Ramboer C, Van De Bruaene P, Inderadjaja N. Cholestatic hepatitis due to an amoxycillin-clavulanic acid preparation. F Hepatol 1989; 9: 260-4.

6 Schneider JE, Kleinman MS, Kupiec JW. Cholestatic hepatitis after therapy with amoxycillin-clavulanate potassium. $N Y$ State F Med 1989; 89: 355-6.

7 Dowsett JF, Gillow T, Heagerty A, Radcliffe M, Toadi R, Isle I, et al. Amoxycillin-clavulanic acid (Augmentin) induced intrahepatic cholestasis. Dig Dis Sci 1989; 34: 1290-3.

8 Stricker BHCh, Van Den Broek JWG, Keuning J, Eberhardt W, Houben HGJ, Johnson M, et al. Cholestatic hepatitis due to antibacterial combination of amoxycillin and clavulanic to antibacterial combination of amoxycillin and cla

9 Pelletier G, Ink O, Fabre M, Hagège $\mathrm{H}$. Hèpatite cholestatique probablement due à l'association d'amoxicilline et d'acide clavulanique. Gastroenterol Clin Biol 1990; 14: 601-7.

10 Michielsen PP, Van Outryve MJ, Van Marck EA, De Maeyer MH, Pelckmans PA, Van Maercke YM. Amoxycillin clavulanic acid induced cholestasis. F Hepatol 1990; 11: 392

11 Cleau D, Jobard JM, Alves T, Gury S, Rey B, Vuillemard M et al. Hépatite cholestatique due à l'association amoxicillineacide clavulanique. Gastroenterol Clin Biol 1990; 14: 1007-9.

12 Smith PM, Wilton A, Routledge PA. Jaundice associated with amoxycillin - clavulanate potassium therapy. Eur $\mathcal{F}$ Gastroenterol Hepatol 1991; 3: 95-6.

13 Augmentin Jaundice. Australian Adverse Drug Reactions Bulletin. November 1990.

14 Royer RJ. Pharmacovigilance. The French system. Drug Safety 1990; 5 (Suppl 1): 137-40.

15 Silvain C, Fort E, Levillain P, Labat-Labourdette J, Morichau-Beauchant $M$. Granulomatous hepatitis due to combination of amoxycillin and clavulanc acid. Dig Dis Sci 1991 (in press).

16 Stricker BHC, Spoelstra P. Drug-induced hepatic injury. $A$ comprehensive survey of the literature on adverse drug reactions up to fanuary 1985. Elsevier; Amsterdam, 1985.

17 Benichou C. Criteria of drug-induced liver disorders. Report of an International consensus meeting. $₹$ Hepatol 1990; 11: 272-6.

18 Trevisani F, Panicone L, Bernardi M, Mazzatti M. Gasbarrini G. Beta-lactam antibiotic-induced cholestasis: synergistic of phenobarbitone plus corticosteroid treatment. Ital f Gastroenterol 1988; 20: 134-6.

19 Van Der Auwera P, Legrand JC. Ticarcillin-clavulanic acid therapy in severe infections. Drugs Exp Clin Res 1985; (Suppl 11): 805-13. 